\title{
PENGARUH PENGGUNAAN MODEL PEMBELAJARAN PROBLEM SOLVING SISTEMATIS TERHADAP HASIL BELAJAR FISIKA DASAR 2 MATERI LISTRIK ARUS SEARAH PADA MAHASISWA PENDIDIKAN FISIKA
}

\author{
${ }^{1}$ Tri Isti Hartini, Martin ${ }^{2}$ \\ tri.isti@yahoo.com \\ ${ }^{1,2}$ Program Studi Pendidikan Fisika, Universitas Muhammadiyah Prof. DR. HAMKA, Jakarta, Indonesia
}

Received: 10 Desember 2020 Revised: 12 Desember 2020

Accepted: 19 Desember 2020

\begin{abstract}
This study aims to determine whether there is an effect of systematic problem solving learning models on basic physics learning outcomes 2. Based on the hypothesis proposed in this study, there is an effect of systematic problem solving learning models on basic physics learning outcomes 2. This research was conducted in the Physics Education Study Program. FKIP UHAMKA. The method used in this research is the experimental method. With the target population in this study were all students of the Physics Education Study Program FKIP UHAMKA, while the affordable population was semester 2 students. The sample was taken randomly (random sampling) by taking 20 students from semester 2 students. The design used in the study was one group pretest-posttest design. The data collection technique used a research instrument in the form of a written test (paper and pencil test), namely a description of 15 questions. Based on the hypothesis test using the t test, the t count was 2.78. While $t$ table is obtained from table $t$ with a significance level of $\alpha=0.05$ and degrees of freedom $(d k)=20$, which is 1.725 . Because $t_{\text {count }}>t_{\text {table }} 2.78>1.725$, HO is rejected. This H1 is accepted, which states that there is an effect of systematic problem solving learning models on student physics learning outcomes on direct current material.
\end{abstract}

\begin{abstract}
Abstrak: Penelitian ini bertujuan untuk mengetahui apakah terdapat pengaruh model pembelajaran problem solving sistematis terhadap hasil belajar fisika dasar 2. Berdasarkan hipotesis yang diajukan dalam penelitian ini adalah terdapat pengaruh model pembelajaran problem solving sistematis terhadap hasil belajar fisika dasar 2. Penelitian ini dilaksanakan di Program Studi Pendidikan Fisika FKIP UHAMKA. Metode yang digunakan dalam penelitian ini adalah metode eksperimen. Dengan populasi target dalam penelitian ini adalah seluruh mahasiswa Program Studi Pendidikan Fisika FKIP UHAMKA, sedangkan populasi terjangkaunya adalah mahasiswa semester 2. Sampel diambil secara acak (random sampling) dengan mengambil 20 mahasiswa yang berasal dari mahasiswa semester 2. Desain yang digunakan pada penelitian adalah one group pretestposttest design. Teknik pengumpulan data menggunakan instrumen penelitian berupa tes tertulis (paper and pencil test) yaitu uraian sebanyak 15 soal. Berdasarkan uji hipotesis dengan menggunakan uji t maka diperoleh $t_{\text {hitung }}$ sebesar 2,78. Sedangkan $t_{\text {tabel }}$ didapat dari tabel $t$ dengan taraf signifikasi $\alpha=0,05$ dan derajat kebebasan $(d k)=20$ yaitu sebesar 1,725 . Karena $t_{\text {hitung }}>t_{\text {tabel }}$ 2,78> 1,725 maka $H_{0}$ ditolak. Dengan demikian $H_{1}$ diterima yang menyatakan bahwa terdapat pengaruh model pembelajaran problem solving sistematis terhadap hasil belajar fisika mahasiswa pada materi arus searah.
\end{abstract}

Kata kunci: Model Pembelajaran, Problem Solving Sistematis, Hasil Belajar Fisika Dasar 2 


\section{PENDAHULUAN}

Pendidikan merupakan unsur yang penting dalam rangka mendukung pembangunan nasional melalui pembentukan sumber daya manusia yang unggul. Hal ini sesuai dengan tujuan pendidikan nasional dalam UU nomor 20 tahun 2003 pada Bab II pasal 3 yaitu:

"Pendidikan nasional berfungsi mengembangkan kemampuan dan membentuk watak serta peradaban bangsa yang bermartabat dalam rangka mencerdaskan kehidupan bangsa, bertujuan untuk berkembangnya potensi peserta didik agar menjadi manusia yang beriman dan bertakwa kepada Tuhan Yang Maha Esa, berakhlak mulia, sehat, berilmu, cakap, kreatif, mandiri, dan menjadi warga negara yang demokratis serta bertanggung jawab."

Oleh karena itu, pendidikan perlu dilaksanakan terpadu, serasi dan teratur serta pelaksanaan pendidikan didukung oleh partisispasi aktif pemerintah, berbagai kelompok masyarakat, pihak orang tua dan dewan kependidikan (Suhendri, H, 2015). Kemajuan dan perkembangan IPTEK yang sangat pesat saat ini tidak lepas dari peran pendidikan sebagai salah satu tolak ukur berkembangnya suatu bangsa. Untuk menguasai IPTEK maka dibutuhkan penguasaan dalam berbagai ilmu, salah satunya adalah fisika. Perkembangan IPTEK tidak hanya menuntut kemampuan menerapkan fisika tapi juga dibutuhkan kemampuan penalaran untuk menyelesaikan berbagai masalah yang akan muncul. Dalam pembelajaran fisika, kemampuan penalaran berperan penting baik dalam pemahaman konsep maupun pemecahan masalah (problem solving) (Agustin, R. D, 2016).

Perkembangan ilmu pengetahuan dan teknologi saat ini sudah sangat pesat. Hal ini menuntut manusia di dalamnya untuk selalu menyesuaikan perkembangan ilmu pengetahuan dan teknologi agar tidak tertinggal. Salah satu bentuk penyesuaiannya adalah dengan belajar kembali, belajar terus, belajar tanpa henti atau dengan kata lain belajar sepanjang hayat. Pengetahuan perlu ditambah, diperbaharui, disesuaikan dengan kemajuan pengetahuan dan teknologi. Perguruan Tinggi memberikan peluang bagi peserta didik untuk bisa mengembangkan ilmu pengetahuan dan teknologi. Pendidikan yang lebih baik juga dapat dicapai melalui Perguruan Tinggi (Rini, E. S, 2012).

Perguruan tinggi harus mencetak lulusan yang berkualitas sebagai bentuk kontribusi kepada bangsa dan negara. Oleh karena itu untuk memperoleh lulusan yang berkualitas tersebut dibutuhkan dosen yang berkompeten pula. Dosen sebagai pemeran penting dalam pendidikan tinggi memiliki andil, tugas dan tanggung jawab penuh. Untuk itu, dibutuhkan dosen yang mampu terus bertekad meningkatkan kualitas manusia tempatnya bertugas, menguasai perkembangan pengetahuan, teknologi dan informasi. Namun realitanya berdasarkan hasil observasi awal, mahasiswa dalam proses pendidikan belum bersinergi 
dengan dosen. Kemampuan mahasiswa dalam memecahkan masalah khususnya dalam permasalahan Fisika masih rendah. Padahal pada hakikatnya fisika merupakan program untuk menanamkan dan mengembangkan kemampuan berpikir, sikap dan nilai ilmiah. Menurut Hegde, salah satu tujuan penting dalam pembelajaran fisika adalah untuk memastikan siswa mampu mempelajari konsep dan menerapkannya ke dalam situasi baru secara efektif (Hegde, 2012). Dalam hal ini jelas bahwa pembelajaran fisika di perguruan tinggi khususnya pada program studi Pendidikan Fisika seharusnya diharapkan menjadi sarana untuk melatih dan mengembangkan sejumlah kemampuan berpikir (thinking skills) mahasiswa agar dapat memecahkan masalah dalam kehidupan bermasyarakat.

Proses pembelajaran Ilmu Pengetahuan Alam (IPA) termasuk fisika mestinya menekankan pada pemberian pengalaman langsung kepada siswa sehingga siswa memperoleh pemahaman mendalamtentang alam sekitar dan prospek pengembangan lebih lanjut dapat menerapkannya di dalam kehidupan kehidupan sehari-hari. Pembelajaran fisika seharusnya melibatkan aspek sikap, proses, produk, dan aplikasi, sehingga siswa dapat mengalamiproses pembelajaran secara utuh, memahami fenomena alam melalui kegiatan pemecahan masalah, metode ilmiah, dan meniru kerja ilmuan dalam menemukan fakta baru (Ariani, T., \& Suanti, W, 2016). Fisika merupakan pelajaran yang mengandalkan kemampuan berhitung, bernalar, dan logika yang baik. Oleh karena itu, peserta didik dituntut untuk memahami konsep-konsep fisika secara terarah. Dengan melakukan hal tersebut, diharapkan peserta didik memiliki kemampuan beralasan, berkomunikasi, memecahkan masalah dan menggunakan fisika dalam kehidupan sehari-hari.

Berdasarkan hasil pengamatan di lapangan, proses belajar mengajar di kelas cenderung bersifat analitis dengan menitikberatkan pada penurunan rumus-rumus fisika melalui analisis matematis. Mahasiswa berusaha menghapal rumus namun kurang memaknai untuk apa dan bagaimana rumus itu digunakan. Metode ceramah dan tanya jawab merupakan metode yang biasa digunakan oleh dosen dengan urutan menjelaskan, memberi contoh, bertanya, latihan, dan memberikan tugas. Soal-soal lebih menekankan manipulasi secara matematis sehingga mahasiswa yang kurang mampu dalam matematika akan merasa sulit untuk belajar fisika dan soal-soal yang dilatihkan sangat jauh dari dunia nyata mahasiswa sehingga pembelajaran Fisika Dasar menjadi kurang bermakna bagi mahasiswa itu sendiri.

Untuk mengatasi permasalahan di atas, diperlukan suatu model pembelajaran alternatif yang bisa mengembangkan kemampuan berpikir mahasiswa. Model pembelajaran yang diterapkan harus menekankan pada aktivitas belajar yang berpusat pada mahasiswa (student 
centered), dimana mahasiswa harus lebih aktif dibandingkan dengan dosen baik dalam perkuliahan serta dalam memecahkan masalah-masalah secara sistematis yang berkaitan dengan fisika dasar.

Model pembelajaran yang efektif menurut Aqib dan Mutadlo adalah model pembelajaran yang memiliki langkah pembelajaran yang sederhana, mudah diterapkan, dapat mencapai hasil belajar optimal, dan salah satu model yang memenuhi kriteria tersebut adalah model problem solving (Aqib \& Mutadlo, 2016). Pembelajaran pemecahan masalah (problem solving) berdasarkan langkah-langkah model problem solving sistematis yang dikembangkan dalam Made Wena dapat menjadi alternatif untuk meningkatkan hasil belajar dan kemampuan pemecahan masalah mahasiswa tersebut. Kebanyakan siswa dapat dengan mudah menerima pengetahuan tantang fisika, tetapi sukar mengaplikasikan pengetahuan secara fleksibel dalam memecahkan masalah. Hal tersebut menjadi kesulitan yang berkembang dalam problem solving Fisika, sehingga sekarang telah ada sebuah metode umum yang efektif untuk pembelajaran Fisika dengan model Problem Solving. Model pembelajaran problem solving sistematis yang berlandaskan pada paradigma kontruktivistik Secara umum pemecahan masalah sistematis terdiri dari empat fase utama, yaitu analisis soal, perencanaan proses penyelesaian soal, operasi perhitungan, dan pengecekan jawaban serta interpretasi hasil (Made Wena, 2009).

Oleh karena itu berdasarkan hasil obervasi awal dan uraian di atas, penulis melakukan penelitian untuk mengetahui pengaruh pembelajaran menggunakan model problem solving sistematis terhadap hasil belajar sehingga dilakukan penelitian dengan judul "Pengaruh Penggunaan Model Pembelajaran Problem Solving Sistematis Terhadap Hasil Belajar Fisika Dasar 2 Materi Listrik Arus Searah Pada Mahasiswa Pendidikan Fisika”

\section{LANDASAN TEORI}

\section{A. Hekekat Hasil Belajar}

Abdurrahman dalam Asep Jihad dan Abdul Haris mengatakan bahwa hasil belajar adalah kemampuan yang diperoleh anak setelah melalui kegiatan belajar. Maksudnya ketika seorang anak telah melakukan aktivitas belajar tertentu, maka ia akan memperoleh hasil belajar tertentu pula ( Asep, 2010). Adapun Nana Sudjana menyatakan hasil belajar dinilai melalui tes, baik tes uraian maupun tes objektif. Pelaksanaan penilaian bisa secara lisan, tulisan, dan tindakan atau perbuatan. Maksud dari penjelasan di atas yaitu keberhasilan mahasiswa tergantung pada pembelajaran seorang dosen dalam memilih pendekatan dan metode untuk 
mencapai prestasi yang optimal, sehingga dapat mengubah perilaku mahasiswa tersebut (Nana Sudjana, 2009).

Sejalan dengan pengertian di atas, Gagne dalam buku Dimyati dan Mujiono berpendapat bahwa hasil belajar berupa kapabilitas, karena setelah belajar orang akan memiliki keterampilan, pengetahuan, sikap dan nilai. Timbulnya kapabilitas tersebut adalah dari stimulasi yang berasal dari lingkungan dan proses kognitif yang dilakukan oleh pembelajar (Dimyati \& Mujiono, 2006). Dengan demikian hasil belajar akan terlihat setelah diberi perlakuan pada proses belajar yang dianggap sebagai proses pemberian pengalaman belajar. Hasil belajar mengharapkan terjadinya perubahan tingkah laku yang terjadi pada diri mahasiswa.

Dari pendapat para ahli di atas, maka dapat disimpulkan bahwa hasil belajar adalah hasil yang diperoleh mahasiswa setelah mengalami pembelajaran. Hasil tersebut dapat berupa pengetahuan, keterampilan, kemampuan, sikap, perkembangan mental, nilai maupun perilaku yang diperoleh mahasiswa setelah berinteraksi dengan sesamanya ataupun dengan lingkungannya. Hasil belajar digunakan oleh dosen untuk dijadikan ukuran atau kriteria dalam mencapai suatu tujuan pembelajaran. Hasil belajar yang baik merupakan tujuan utama dalam pembelajaran maka untuk mencapainya perlu adanya cara atau teknik yang baik pula dalam prosesnya, karena hasil belajar dapat dijadikan tolak ukur apakah ia berhasil atau tidak dalam melaksanakan proses pembelajaran.

\section{B. Hakekat Model Pembelajaran Problem Solving Sistematis}

Pemecahan masalah sistematis adalah suatu cara pembelajaran dengan menghadapkan peserta didik kepada suatu masalah untuk dipecahkan atau diselesaikan. Di mana dalam pemecahan masalah sistematis ini peserta didik didorong dan diberi kesempatan seluasluasnya untuk berinisiatif dan berpikir secara sistematis (mengerjakan selangkah demi selangkah) dalam menghadapi suatu masalah dengan menerapkan pengetahuan yang didapat sebelumnya (Muliati, M. ,2015).

Pemecahan masalah sistematis (Systematic Approach to Problem Solving) adalah petunjuk untuk melakukan suatu tindakan yang berfungsi untuk membantu seseorang dalam menyelesaikan suatu permasalahan (Made Wena, 2009). Secara garis besar operasional tahap-tahap pemecahan masalah sistematis terdiri atas empat tahap berikut :

1. Memahami masalahnya

2. Membuat rencana penyelesaian

3. Melaksanakan rencana penyelesaian

Puplished at https://ojs.stkippgri-lubuklinggau.ac.id/index.php/SJPIF 
4. Memeriksa kembali, mengecek kembali

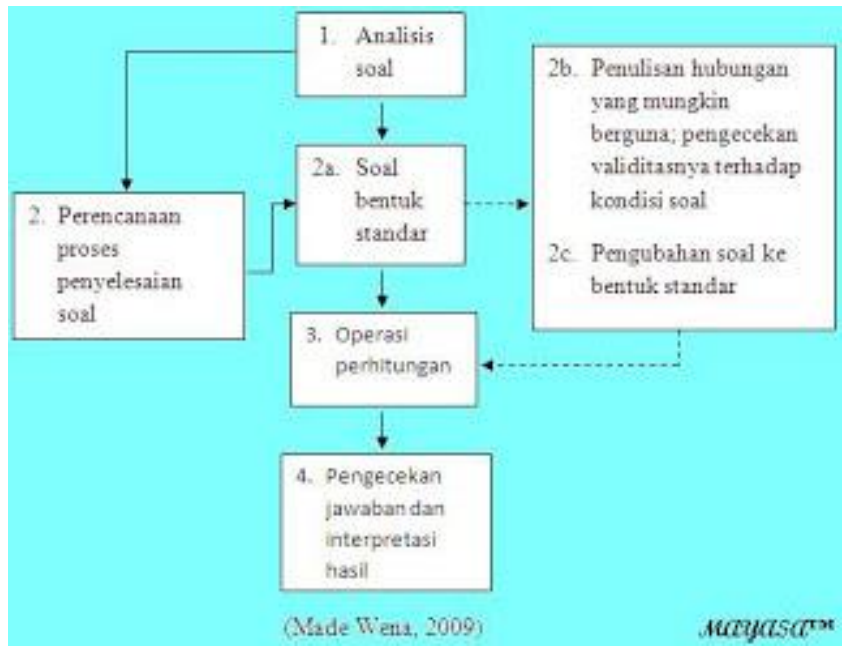

Gambar 1. Systematic Problem Solving

Secara operasional tahap-tahap pemecahan masalah tersebut dapat dijelaskan sebagai berikut :

\section{Analisis Soal}

a. Tujuan:

Memperoleh gambaran yang menyeluruh tentang data yang diketahui dan besaran yang tidak diketahui (ditanyakan).

b. Kegiatan Dosen :

Membimbing mahasiswa secara bertahap untuk melakukan analisis soal.

c. Kegiatan Mahasiswa :

- Membaca seluruh soal yang diberikan secara seksama.

- Mentransformasi soal ke bentuk skema yang menggambarkan situasi soal.

- Menulis besaran yang ditanyakan.

- Memperkirakan jawaban (tanda, besaran, dan dimensi).

\section{Transformasi Soal}

a. Tujuan :

Mengubah soal ke bentuk standar.

b. Kegiatan Dosen :

Membimbing mahasiswa melakukan transformasi soal.

c. Kegiatan Mahasiswa :

- Mengecek apakah soalnya sudah berbentuk standar? Jika ya lanjutkan ke fase 3, jika tidak ikuti langkah selanjutnya. 
- Menulis rumus/ hubungan antar besaran yang akan digunakan.

- Mengubah soal ke bentuk standar.

\section{Operasi Perhitungan}

a. Tujuan :

Memperoleh jawaban soal.

b. Kegiatan Dosen :

Membimbing mahasiswa melakukan operasi hitungan.

c. Kegiatan Mahasiswa :

- Mensubstitusikan data yang diketahui ke dalam bentuk standar yang telah diperoleh, kemudian melakukan perhitungan.

- Mengecek apakah tanda dan satuan sudah sesuai.

\section{Pengecekan dan Interpretasi}

a. Tujuan :

Mengecek apakah soal sudah diselesaikan dengan benar dan lengkap.

b. Kegiatan Dosen :

Membimbing mahasiswa melakukan pengecekan terhadap hasil penyelesaian soal.

c. Kegiatan Mahasiswa :

- Mengecek jawaban dengan cara membandingkan dengan perkiraan jawaban yang dibuat pada fase 1 .

- Mengecek apakah jawaban sudah sesuai dengan yang ditanyakan.

- Menelusuri kesalahan-kesalahan apa yang telah dilakukan.

Penggunaan pemecahan masalah sistematis dalam menyelesaikan suatu masalah dilengkapi dengan Key Relation Chart (KR Chart), yaitu lembaran yang berisi catatan tentang persamaan, rumus, dan hukum dari materi yang dipelajari. KR Chart digunakan untuk memudahkan mengingat dan memunculkan kembali hubungan yang diperlukan untuk menyelesaikan latihan soal yang sedang dihadapi (Made Wena, 2009).

\section{METODE PENELITIAN}

Metode yang digunakan dalam penelitian ini adalah Quasi Eksperimen dengan desain yang digunakan adalah pretest-posttest eksperimen desain. Dalam pretest-posttest eksperimen desain, mahasiswa diberikan 2 tes yaitu pretest dan posttest. Dengan soal pretest dan soal posttest adalah soal yang sama dan berbentuk essay. Pengaruh model problem solving 
sistematis terhadap hasil belajar dianalisis menggunakan uji t terhadap rata-rata nilai posttest kedua kelas.

Dalam penelitian ini, untuk menentukan pengaruh model problem solving sistematis terhadap hasil belajar kognitif adalah dengan menggunakan uji t. Uji normalitas dilakukan untuk mengetahui apakah sampel berdistribusi normal atau tidak. Uji normalitas yang digunakan yaitu uji lilliefors galat taksiran pada taraf signifikansi $\alpha=0,05$. Uji homogenitas menggunakan uji Bartlett pada taraf signifikansi $\alpha=0,05$. Sedangkan untuk menguji hipotesis digunakan uji-t dengan persamaan sebagai berikut:

$$
t_{h}=\frac{|\bar{Y}-\bar{X}|}{\sqrt{S_{X}^{2}+S_{Y}^{2}-2 r_{X Y} S_{\bar{X}} S_{\bar{Y}}}}
$$

Dimana:

$$
r_{x y}=\frac{N \sum X Y-\left(\sum X\right)\left(\sum Y\right)}{\sqrt{\left\{N \sum X^{2}-\left(\sum X\right)^{2}\right\}\left\{N \sum Y^{2}-\left(\sum Y\right)^{2}\right\}}}
$$

Setelah nilai $t_{\text {hitung }}$ diperoleh, kemudian dibandingkan dengan $t_{\text {tabel }}$ untuk menguji hipotesis. Kriteria pengujian hipotesis dengan taraf signifikansi $\alpha=0,05$ dan $\alpha=0,01$ yaitu:

Tolak $\mathrm{H}_{0}$ jika $\mathrm{t}_{\text {hitung }}>\mathrm{t}_{\text {tabel}}$,

Terima $\mathrm{H}_{0}$ jika $\mathrm{t}_{\text {hitung }}<\mathrm{t}_{\text {tabel }}$, terdapat pengaruh model pembelajaran problem solving Sistematis terhadap hasil belajar Fisika Dasar 2 materi Listrik Arus Searah.

tidak terdapat pengaruh model pembelajaran problem solving Sistematis terhadap hasil belajar Fisika Dasar 2 materi Listrik Arus Searah.

\section{HASIL DAN PEMBAHASAN}

Penelitian ini bertujuan untuk mengetahui apakah terdapat pengaruh model pembelajaran problem solving sistematis terhadap hasil belajar fisika dasar 2. Dari data yang diperoleh jumlah mahasiswa yang dijadikan sampel pada kelas eksperimen yaitu kelas yang diberikan pembelajaran menggunakan model pembelajaran Problem Solving Sistematis berjumlah 20 mahasiswa didapatkan hasil pretest dan posttest sebagai berikut: 
Tabel 1. Data Hasil Belajar Fisika Dasar 2

\begin{tabular}{ccc}
\hline Kode Siswa & Pretest & Posttest \\
\hline $\mathbf{X}_{\mathbf{1}}$ & 40 & 71 \\
$\mathbf{X}_{\mathbf{2}}$ & 45 & 80 \\
$\mathbf{X}_{\mathbf{3}}$ & 35 & 74 \\
$\mathbf{X}_{\mathbf{4}}$ & 50 & 84 \\
$\mathbf{X}_{\mathbf{5}}$ & 40 & 70 \\
$\mathbf{X}_{\mathbf{6}}$ & 25 & 61 \\
$\mathbf{X}_{\mathbf{7}}$ & 45 & 74 \\
$\mathbf{X}_{\mathbf{8}}$ & 48 & 79 \\
$\mathbf{X}_{\mathbf{9}}$ & 45 & 75 \\
$\mathbf{X}_{\mathbf{1 0}}$ & 49 & 85 \\
$\mathbf{X}_{\mathbf{1 1}}$ & 38 & 70 \\
$\mathbf{X}_{\mathbf{1 2}}$ & 42 & 81 \\
$\mathbf{X}_{\mathbf{1 3}}$ & 40 & 80 \\
$\mathbf{X}_{\mathbf{1 4}}$ & 29 & 70 \\
$\mathbf{X}_{\mathbf{1 5}}$ & 35 & 78 \\
$\mathbf{X}_{\mathbf{1 6}}$ & 30 & 68 \\
$\mathbf{X}_{\mathbf{1 7}}$ & 25 & 60 \\
$\mathbf{X}_{\mathbf{1 8}}$ & 15 & 50 \\
$\mathbf{X}_{\mathbf{1 9}}$ & 29 & 67 \\
$\mathbf{X}_{\mathbf{2 0}}$ & 24 & 66 \\
\hline
\end{tabular}

Berdasarkan data di atas, diperoleh rata-rata pretest hasil belajar untuk kelas eksperimen yaitu 36,45. Untuk postest hasil belajar diperoleh nilai rata-rata yaitu 72,15.

\section{Uji Normalitas}

Uji normalitas yang digunakan untuk kelas eksperimen yaitu uji lilliefors galat taksiran pada taraf signifikan $\alpha=0,05$.

Tabel 2. Hasil Uji Normalitas

\begin{tabular}{ccccc}
\hline Kelas & $\mathbf{N}$ & $\mathbf{L}_{\text {hitung }}$ & $\mathbf{L}_{\text {tabel }}$ & Kesimpulan \\
\hline Eksperimen & 20 & 0,1344 & 0,190 & Normal \\
\hline
\end{tabular}

Berdasarkan hasil pengujian, didapat harga $\mathrm{L}_{\text {hitung }}$ sebesar 0,1344 , sedangkan harga $\mathrm{L}_{\text {tabel }}$ pada $\alpha=0,05$ dengan $\mathrm{dk}=20$ yaitu sebesar 0,190. Dengan demikian $\mathrm{L}_{\text {hitung }}<\mathrm{L}_{\text {tabel }}$ yaitu $0,1344<0,190$, hasil ini menunjukkan bahwa skor galat taksiran $\mathrm{Y}$ atas $\mathrm{X}$ berasal dari populasi yang berdistribusi normal. 


\section{Uji Homogenitas}

Uji homogenitas yang digunakan dalam penelitian ini adalah uji Bartlett pada taraf signifikan $\alpha=0,05$.

Tabel 3. Hasil Uji Homogenitas

\begin{tabular}{ccccc}
\hline Kelas & $\mathbf{N}$ & $\chi^{2}{ }_{\text {hitung }}$ & $\chi_{\text {tabel }}^{2}$ & Kesimpulan \\
\hline Eksperimen & 20 & 4,683 & 12,592 & Homogen \\
\hline
\end{tabular}

Berdasarkan hasil pengujian, diperoleh nilai $\chi^{2}$ hitung sebesar 4,683, sedangkan harga $\chi_{\text {tabel }}^{2}$ pada $\alpha=0,05$ dengan $\mathrm{dk}=20$ yaitu sebesar 12,592 . Dengan demikian $\chi_{\text {hitung }}^{2}<\chi_{\text {tabel }}^{2}$ yaitu 4,683 < 12,592 sehingga terima $\mathrm{H}_{0}$. Hasil pengujian ini dapat disimpulkan bahwa pengelompokan data posttest atas pretest memiliki varians yang homogen.

\section{Pengujian Hipotesis}

Pada pengujian hipotesis digunakan rumus uji-t pada taraf signifikan $\alpha=0,05$ dan derajat kebebasan (dk) 20.

Tabel 4. Hasil Uji Hipotesis dengan Menggunakan Uji t

\begin{tabular}{lcccc}
\hline \multicolumn{1}{c}{ Variabel } & $\mathbf{t}_{\text {hitung }}$ & $\begin{array}{c}\mathbf{t}_{\text {tabel }} \\
\mathbf{\alpha = 0 , 0 5}\end{array}$ & Kesimpulan \\
\hline $\begin{array}{l}\text { Model pembelajaran problem solving } \\
\text { Sistematis terhadap hasil belajar Fisika Dasar 2 } \\
\text { materi Listrik Arus Searah }\end{array}$ & & & \\
\hline
\end{tabular}

Berdasarkan hasil pengujian, diperoleh $t_{\text {hitung }}$ sebesar 2,78, sedangkan dari daftar nilai kritis uji-t dengan taraf signifikasi $\alpha=0,05$ dan derajat kebebasan (dk) 20 diperoleh $t_{\text {tabel }}$ sebesar 1,725. Karena pada $\alpha=0,05 \mathrm{t}_{\text {hitung }}>\mathrm{t}_{\text {tabel }}$ yaitu $2,787>1,725$, maka $\mathrm{H}_{0}$ ditolak. Dengan demikian $\mathrm{H}_{1}$ diterima yang menyatakan bahwa terdapat pengaruh model pembelajaran problem solving Sistematis terhadap hasil belajar Fisika Dasar 2 materi Listrik Arus Searah.

Hasil penelitian ini sesuai dengan hasil penelitian yang telah dilakukan oleh Warimun yang menunjukkan bahwa pembelajaran dengan menggunakan model problem solving dapat terjadi peningkatan penguasaan konsep fisika dan kemampuan problem solving mahasiswa (Warimun, 2018). Hasil ini juga sejalan dengan penelitian yang dilakukan oleh Sijabat dan Motlan. Berdasarkan hasil penelitiannya didapatkan bahwa ada perbedaan hasil belajar yang 
menggunakan model pembelajaran problem solving dan model konvensional, yaitu siswa yang belajar dengan model problem solving memiliki hasil belajar yang lebih baik (Sijabat, Motlan, \& Derlina, 2016).

Melalui pembelajaran dengan model problem solving sistematis, mahasiswa dilatih untuk memahami masalah, membuat rencana penyelesaian, melaksanakan rencana penyelesaian serta memeriksa dan mengecek kembali hasil penyelesaian masalah. Mahasiswa juga diajarkan untuk selalu memahami dulu permasalahan yang diberikan, sebelum menyelesaikannya langsung dengan persamaan matematis. Sedangkan mahasiswa yang belajar menggunakan pembelajaran langsung cenderung pasif karena selama proses pembelajaran berlangsung dosen menjadi sumber belajar utama (teacher centered). Melalui model problem solving sistematis juga, mahasiswa lebih mudah mengkonstruksi pengetahuan, menggali ide-ide yang berkaitan dengan konsep-konsep esensial, memperdalam konsep-konsep sehingga ide-ide yang muncul dapat dikembangkan. Hal ini disebabkan karena pengetahuan yang mereka dapat dari pembelajaran membimbing mahasiswa menyusun lingkungan belajar dan memilih strategi yang tepat, mahasiswa menjadi semakin percaya diri dan menjadi pebelajar yang mandiri, menyadari bahwa mereka dapat memenuhi kebutuhan intelektual sendiri, menemukan banyak informasi oleh tangan mereka sendiri, dan menyadari bahwa disaat mereka menghadapi masalah akan mencoba mencari jalan keluar (Mariati, P. S, 2012).

\section{SIMPULAN DAN SARAN}

\section{A. Kesimpulan}

Terdapat pengaruh model pembelajaran problem solving sistematis terhadap hasil belajar fisika dasar 2 materi Listrik Arus Searah. Hal ini ditunjukkan dari nilai uji-t dengan taraf signifikasi $\alpha=0,05$ dan derajat kebebasan (dk) 20 diperoleh $t_{\text {tabel }}$ sebesar 1,697. Karena pada $\alpha=0,05 \mathrm{t}_{\text {hitung }}>\mathrm{t}_{\text {tabel }}$ yaitu $2,787>1,725$, maka $\mathrm{H}_{0}$ ditolak. Dengan demikian $\mathrm{H}_{1}$ diterima yang menyatakan bahwa terdapat pengaruh model pembelajaran problem solving Sistematis terhadap hasil belajar Fisika Dasar 2 materi Listrik Arus Searah.

\section{B. Saran}

Melalui penelitian ini, peneliti berharap agar para dosen dalam memberikan kuliah menerapkan model pembelajaran yang sesuai dengan materi yang diajarkan. Model pembelajaran Problem Solving Sistematis dapat menjadi model pembelajaran alternatif dalam memberikan perkuliahan fisika dasar 2 di kelas eksperimen. 


\section{DAFTAR PUSTAKA}

Agustin, R. D. (2016). Kemampuan penalaran matematika mahasiswa melalui pendekatan problem solving. PEDAGOGIA: Jurnal Pendidikan, 5(2), 179-188.

Ariani, T., \& Suanti, W. (2016). Efektivitas Penggunaan Model Pembelajaran Problem Based Learning (PBL) Pada Pembelajaran Fisika Siswa Kelas VIII SMP Negeri 2 Lubuklinggau Tahun Pelajaran 2015/2016. Jurnal Inovasi dan Pembelajaran Fisika, 3(2).

Aqib, Z., \& Mutadlo. (2016). Kumpulan Metode Pembelajaran Kreatif dan Inovatif. Bandung: PT Sarana Tutorial Nurani Sejahtera.

Dimyati dan Mudjiono. (2006). Belajar dan Pembelajaran. Jakarta: Rineka Cipta.

Hegde, B. (2012). How do they solve it? An insight into the learner's approach to the mechanism. Physics Education Research, 1(8), 1-9.

Mariati, P. S. (2012). Pengembangan model pembelajaran fisika berbasis problem solving untuk meningkatkan kemampuan metakognisi dan pemahaman konsep mahasiswa. Jurnal pendidikan fisika indonesia, 8(2).

Muliati, M. (2015). Penerapan Strategi Pemecahan Masalah Sistematis (Systematic Approach to Problem Solving) terhadap Hasil Belajar Fisika pada Siswa Kelas VIII MTs DDI Parang Sialla Kab. Jeneponto (Doctoral dissertation, Universitas Islam Negeri Alauddin Makassar).

Rini, E. S. (2012). Hubungan tingkat pendidikan orang tua dan prestasi belajar siswa dengan minat siswa melanjutkan studi ke perguruan tinggi pada siswa kelas XI SMA Negeri 1 Kalasan tahun ajaran 2011/2012. Kajian Pendidikan Akuntansi Indonesia, 1(2).

Sijabat, A., Motlan, \& Derlina. (2016). Pengaruh Model Pembelajaran Model Problem Solving dan Pemahaman Konsep Terhadap Hasil Belajar Fisika Siswa. Jurnal Pendidikan Fisika, 5(2), 87-91.

Sudjana, Nana. (2009). Penilaian Hasil Proses Belajar Mengajar. Bandung: Remaja Rosdakarya.

Suhendri, H. (2015). Pengaruh metode pembelajaran problem solving terhadap hasil belajar matematika ditinjau dari kemandirian belajar. Formatif: Jurnal Ilmiah Pendidikan MIPA, 3(2).

Sugiyono. (2012). Metode Penelitian Pendidikan Pendekatan Kuantitatif, Kualitatif, dan $R \& D$. Bandung: Alfabeta.

Warimun, E. S. (2018). Pengaruh Pembelajaran dengan Model Problem Solving Fisika terhadap Pemahaman Konsep dan Kemampuan Problem Solving pada Mahasiswa Pendidikan Fisika. Prosiding Seminar Nasional EduFisika, Jakarta, 3 Maret.

Wena, Made. (2009). Strategi Pembelajaran Inovatif Kontemporer: Suatu Tinjauan Konseptual Operasional. Jakarta: Bumi Aksara. 